\title{
PENGARUH KANDUNGAN PARTIKEL SERBUK GENTENG SOKKA TERHADAP KEKUATAN TARIK DAN KEKUATAN IMPAK PADA KOMPOSIT BERMATRIKS EPOXY
}

\author{
Fajar Nugroho \\ Departemen Teknik Mesin \\ Sekolah Tinggi Teknologi Adisutjipto \\ Jl. Janti Blok R Lanud Adisutjipto Yogyakarta. \\ Email : mas_noeg@yahoo.com
}

\begin{abstract}
Composites consist of two or more separate materials combined in a macroscopic structure. This is different from alloy which is the structural unit is formed microscopiccally. At this research, the composite reinforcement was made of sokka Kebumen powder tile using epoxy formatrix. The percentage variations of volume fraction are $0 \%, 10 \%, 20 \%, 30 \%$, and $40 \%$ with a mesh size of 180-200 mesh. This study aims to determine the tensile strength, impact strength, and SEM. The method used during the manufacturing process of composite was vacum molding. The tensile strength test showed the highest value was at 10\% volume fraction with 49,946 $\mathrm{MPa}$. The lowest value was at $40 \%$ volume fraction with $27,618 \mathrm{MPa}$. The impact strength test showed the highest value was at $10 \%$ volume fraction with $0,03925 \mathrm{~J} / \mathrm{mm} 2$. The lowest value was at $40 \%$ volume fraction with $0,03375 \mathrm{~J} / \mathrm{mm} 2$. The higher the percentage volume fraction of sokka tile powder, the lower the tensile strength and the impact strength of the composites have. The SEM test showed that there was still pull out at the side.
\end{abstract}

Keywords : sokka tile powder, epoxy, volume fraction, composite.

1. Pendahuluan

Limbah genteng atau yang biasa dikenal dengan sebutan kreweng selama ini hanya dimanfaatkan untuk pengurukan lahan yang tidak rata. Pemanfaatan limbah genteng dengan cara tersebut tentunya kurang memeberikan nilai ekonomis yang baik. Apa lagi jika dilihat pada sentra-sentra industri genteng yang terbuat dari tanah liat seperti di Godean Kab. Sleman atau juga seperti di daerah Sokka, kabupaten Kebumen -Jawa Tengah. Dalam saat produksi terutama pasca proses pembakaran biasanya akan terdapat genteng cacat produksi atau pecah yang tidak dapat diolah kembali atau didaur ulang menjadi genteng baru. Limbah genteng tersebut semakin banyak dan menumpuk di perusahaan-perusahaan genteng atau di lokasi-lokasi pemukiman dan perumahan yang menggunakan jenis genteng tersebut.

Agar memiliki nilai tambah maka limbah genteng dari tanah liat tersebut maka diperlukan usaha inovatif dalam memanfaatkan limbah tersebut. Salah satu cara pemanfaatan limbah genteng adalah dengan menggilingnya dalam bentuk serbuk untuk dimanfaaatkan dalam berbagai keperluah. Selanjutnya serbuk yang dihasiljan bisa diproses lebih lanjut sebagai bahan penguat dalam pembuatan komposit. Dengan adanya inovasi bahan komposit maka diharapkan bisa diperoleh material komposit berbahan penguat serbuk genteng. Dengan berkembangnya material komposit yang sangat pesat maka peluang mengembang produk material komposit yang ringan namun memiliki karakteristik yang sepadan dengan logam sangat terbuka lebar. Hal ini ditunjang oleh berkembangnya teknologi komposit geopolimer yang merupakan terobosan teknologi bagi dunia industri. Metode ini memiliki keunggulan pada proses binder dengan kinerja tinggi akibat adanya aluminium oksida (Alumina $\mathrm{Al}_{2} \mathrm{O}_{3}$ ) dan silikon oksida (Silika - $\mathrm{SiO}_{2}$ ). Kedua senyawa ini terdapat pada material genteng lempung Sokka dalam bentuk Montmorillonite (MMt) 
Penelitian tentang pemanfaatan limbah genteng sokka sebagai bahan komposit sudah dilakukan oleh beberapa orang peneliti, baik yang digunakan dalam bentuk material pengisi/filler pada bahan kontruksi maupun yang dalam bentuk serbuk dengan berbagai ukuran butiran sebagai bahan untuk rekayasa material khususnya komposit dengan penguat berbentuk partikel.

Ukuran dan jumlah kandungan partikel serbuk genting sokka mempunyai pengaruh yang sangat besar terhadap kekuatan mekanik komposit berbasis matrik polyester. Penambahan partikel serbuk genting dengan ukuran yang semakin kecil akan menghasilkan komposit yang memiliki kekuatan yang lebih baik dibandingkan dengan penambahan partikel dengan ukuran yang lebih besar. Semakin kecil ukuran partikel maka akan diperoleh ikatan yang semakin baik. namun penambahan kandungan partikel serbuk genteng ini tidak berbanding lurus dengan ukuran partikel. Kandunganpartikel yang terlalubesar justru menyebabkan kekuatan komposit yang dihasilkan justru menurun lagi meskipun masih lebih baik jika dibandingkan tanpa penguat serbuk genting sokka. [1].

Selanjutnya bentuk dari partikel serbuk penguat pada kompositjuga sangat berpengaruh terhadap kekuatan mekanik baik makro maupun mikro mekaniknya. Pada umumnya partikel fly ash adalah bulat, sedang partikel serbuk genteng sokka berbentuk campuran bulat dengan amorft dan partikel clay lokal umumya berbentuk amorf serpih. Hasil dari berbagai kajian dan analisis pada partikel material tersebut menunjukan bahwa komposit dengan penguat partikel serbuk dalam ukuran nanosilica/phenolic memiliki kekuatan lebih tinggi dibandingkan dengan komposit geopolimer lainnya. [2,3]

Penambahan kandungan dan ukuran serbuk genteng sokka juga mampu meningkatakan ketahanan bakar dari komposit geopolimer. Hal ini ditunjukan dengan meningkatnya time of burning dari komposit yang dihasilkan ketika diuji nyala. Selanjutnya penambahan serbuk genteng sokka mampu meningkatkan ketahanan bakar komposit SGS-ripoxy R-802. Ukuran serbuk genteng sokka juga berpengaruh terhadap laju pembakaran dimana ukuran partikel yang lebih kecil (kurang dari 74 $\mu \mathrm{m})$, menyebabkan peningkatan time of burning dan penurunan rate of burning. Perilaku ini menunjukan bahwa ukuran butir serbuk genteng sokka yang kecil mampu meningkatkan ketahanan[3].

Kemudian penambahan serbuk genteng sebagai pengisi pada komposit high density polyethelene (HDPE) juga berengaruh terhadap sifat lentur/kelenturan dari komposit HDPE. Peningkatan jumlah fraksi volume genteng memberikan efek pada penurunan kemampuan matrik komposit yang tidak dapat mengikat antar permukaaan partikel genteng dengan baik sehingga komposit mengalami penurunan elastisitas (komposit semakin kaku). Komposit HDPEserbuk genteng ini dapat diaplikasikan sebagai material pada komponen kendaraan yang tidak dipesyaratkan kekuatan bending yang tinggi misalnya board kendaraan [4].

Kandungan partikel genteng sokka mempunyai pengaruh terhadap kekuatan impak pada komposit dengan penguat serat karbon dan serbuk genteng sokka. Bertambahnya fraksi volume serat dan diikuti berkurangnya fraksi volume partikel mengakibatkan kekuatan impak komposit serat karbon - serbuk genteng sokka Phenolic semakin meningkat. Pada Komposisi fraksi volume serat/partikel yang sama, kekuatan impak komposit dengan orientasi serat $\pm 45^{\circ}$ lebih besar dibandingan kekuatan impak pada komposit dengan orientasi $0 / 90^{\circ}[5]$. Bentuk patahan komposit bermatrik phenolic dengan penguat serat karbon dan serbuk genteng sokka menunjukan bahwa serat karbon mengalami patah ulet sedangkan bagian komposit yang memiliki kandungan sebuk genteng sokka yang besar mengalami patah getas [5].

Serbuk genteng sokka mengandung unsur aluminium oksida/alumina $\left(\mathrm{Al}_{2} \mathrm{O}_{3}\right)$ dan senyawa silikon oksida/silika $\left(\mathrm{SiO}_{2}\right)$ dalam prosentase yang cukup besar. Kandungan $\mathrm{Al}_{2} \mathrm{O}_{3}$ berfungsi untuk meningkatkan ketahanan nyala api, sedang $\mathrm{SiO}_{2}$ berfungsi meningkatkan sifat mekanis. Komposisi terbaik komposit dengan kandungan partikel $40 \%$, ukuran butiran 74 um dan $15 \%$ laminate serat gelas. Komposisi ini memiliki nilai kekuatan tarik 
207,51 Mpa dan modulus tarik 3,395 Gpa. Ketahanan bakar meningkat seiring dengan penambahan lapisan serat gelas dan kandungan serbuk. Nilai kandungan tertinggi time to ignition 17,62 detik dan burning rate $0,23 \mathrm{~mm} / \mathrm{detik}$ diperoleh pada prosentase kandungan serat gelas dan serbuk $40 \%$, ukuran butiran $<74$ um dan serat gelas 13 laminate [6].

\section{Metode Penelitian}

Material komposit yaitu material yang tersusun dari dua kombinasi atau lebih unsur-unsur utama yang secara makro berbeda dalam bentuk dan atau komposisi material yang pada dasarnya tidak dapat dipisahkan. Kelebihan material komposit dibandingkan dengan material logam adalah ketahanan terhadap korosi, bahan yang mudah dicari, harga yang cukup terjangkau, serta memiliki massa jenis yang lebih rendah dibandingkan dengan bahan dari logam [7].

Pada umumnya komposit terdiri dari penguat dan matrik. Penguat biasanya berbentuk partikel, serat atau gabungan dari keduanya. Matrik dibutuhkan untuk mengikat antar partikel atau serat yang satu dengan yang lainya. Fungsi utama matrik adalah sebagai bahan pengikat dan penguat. Penguat merupakan komponen di dalam material komposit yang bertujuan untuk memperbaiki sifat mekanik dari bahan matrik yang digunakan [8].

\subsection{Resin Epoxy}

Epoxy termasuk dalam jenis polimer thermoset. Resin epoxy memiliki kelebihan sifat mekanik sehingga sering digunakan dalam bidang teknologi komposit. Resin epoxy membutuhkan waktu yang lebih lama untuk menghasilkan kualitas material yang baik dengan siklus transformasinya \pm 10 jam pada temperatur yang tinggi $\left(50^{\circ}\right.$ s.d. $100^{\circ} \mathrm{C}$ ). Kelebihan resin epoxy jika dibandingkan dengan jenis resin lainnya adalah; memiliki kemampuan sifat mekanik yang baik, lebih tahan pada suhu tinggi, tahan terhadap cairan kimia, memiliki prosentase penyusutan yang baik yaitu kurang dari $1 \%$, merupakan zat adhesif yang baik untuk material metalik. Namun resin epoxy juga memiliki kekurangan yaitu proses polimerisasi cukup lama, harga yang relatif lebih mahal, membutuhkan perlakuan khusus saat proses pembuatan, serta sensitif terhadap retakan. Tabel 1 merupakan garis besar dari sifat mekanik dari resin epoxy .

Tabel 1. Data teknis resin epoxy

\begin{tabular}{|l|c|}
\hline \multicolumn{1}{|c|}{ Jenis Sifat Mekanik } & Jangkauan Nilai \\
\hline Density & $1100-1500$ \\
Tensile Modulus & $\mathrm{kg} / \mathrm{m}^{3}$ \\
Tensile Strength & $3-5 \mathrm{GPa}$ \\
Flexural Strength & $60-80 \mathrm{MPa}$ \\
Tensile Elongation & $100-150 \mathrm{MPa}$ \\
Shear Strength Deflection & $2-5 \%$ \\
Heat & $30-50 \mathrm{MPa}$ \\
Temperature & $290^{\circ} \mathrm{C}$ \\
\hline
\end{tabular}

\subsection{Serbuk Genteng}

Bahan yang digunakan dapat berupa serbuk atau serpih. Namun, bahan berbentuk serat lebih banyak digunakan dalam komposit polimer karena lebih efektif dibandingkan dengan bahan yang berbentuk serbuk atau serpih [9]. Untuk dapat menghasilkan produk komposit yang efektif, bahan penguat hendaknya harus memenuhi dua kriteria, yaitu komponen harus memiliki modulus elastisitas yang lebih tinggi dari pada matriksnya dan harus ada ikatan yang kuat antara komponen penguat dan matriks.

Salah satu penguat yang baik adalah serbuk genteng. Serbuk genteng mempunyai kandungan senyawa yang baik untuk memeperkuat komposit yang dihasilkan. Genteng merupakan bahan yang terbuat dari tanah lempung. Tanah lempung yang digunakan sebagai genteng memiliki ketahanan terhadap panas bakar yang tinggi serta kekerasan yang baik. Dalam berbagai aplikasi serbuk genteng telah digunakan sebagai pengisi pada rekayasa material komposit. Komposit partikel adalah material komposit yang memanfaatkan partikel sebagai pengisi komposit. Keunggulan komposit partikel adalah mempunyai ketahanan terhadap aus, tidak mudah retak dan mempunyai daya pengikat dengan matrik yang baik. Serbuk genteng sokka memiliki kandungan utama berupa silika $\left(\mathrm{SiO}_{2}\right)$ dan alumina $\left(\mathrm{Al}_{2} \mathrm{O}_{3}\right)$ dengan konsentrasi kandungan $54,59 \%$ dan $19,62 \%$. Kedua kandunagan tersebut dapat menghambat adanya perambatan api flame 
resistance). Flame resistance merupakan komponen atau kombinasi yang dapat menghambat nyala bila ditambahkan pada suatu material yang memiliki kemampuan hambat nyala.

Tanah liat mempunyai sifat susut kering yang cukup besar. Sifat susut kering merupakan perubahan bentuk (penyusutan) pada tanah liat yang akan dibentuk, misalnya: genteng dan batu bata pada saat dikeringkan. Besarnya susut kering ini dipengaruhi oleh besarnya butir, banyaknya air pembentuk, cara pembentukan dan suhu pembentukan. Tanah liat memiliki kandungan susunan kimia yang terdiri dari mineral aluminium oksida $\left(\mathrm{Al}_{2} \mathrm{O}_{3}\right)$, senyawa silika $\left(\mathrm{SiO}_{2}\right)$, senyawa kapur, senyawa magnesium oksida $(\mathrm{MgO})$, kalsium oksidadolomite, serta senyawa besi oksida ( $\left.\mathrm{Fe}_{2} \mathrm{O}_{3}\right)$. Tabel 2. Kandungan Serbuk Genteng Sokka

\begin{tabular}{|c|c|c|}
\hline $\begin{array}{c}\text { Kandungan } \\
\text { Kimia }\end{array}$ & $\begin{array}{c}\text { Konsentrasi } \\
\% \text { wt. }\end{array}$ & $\begin{array}{c}\text { Unsur } \\
\text { Dominan }\end{array}$ \\
\hline $\mathrm{SiO}_{2}$ & 54,59 & $\mathrm{Si}$ \\
\hline $\mathrm{Al}_{2} \mathrm{O}_{3}$ & 19,62 & $\mathrm{Al}$ \\
\hline $\mathrm{Fe}_{2} \mathrm{O}_{3}$ & 13,30 & $\mathrm{Fe}$ \\
\hline $\mathrm{CaO}$ & 3,55 & $\mathrm{Ca}$ \\
\hline $\mathrm{MgO}$ & 3,03 & $\mathrm{Mg}$ \\
\hline $\mathrm{K}_{2} \mathrm{O}$ & 2,25 & $\mathrm{~K}$ \\
\hline $\mathrm{TiO}$ & 1,40 & $\mathrm{Ti}$ \\
\hline $\mathrm{P}_{2} \mathrm{O}_{3}$ & 0,69 & $\mathrm{P}$ \\
\hline $\mathrm{SO}_{3}$ & 0,37 & $\mathrm{~S}$ \\
\hline $\mathrm{Cl}$ & 0,35 & $\mathrm{Cl}$ \\
\hline
\end{tabular}

\subsection{Metode Pembuatan Komposit Hand Lay-Up}

Adapun proses dari pembuatan dengan metoda ini adalah dengan cara menuangkan resin dengan tangan kedalam serat berbentuk anyaman, rajutan atau kain, kemudian memberi tekanan sekaligus meratakannya menggunakan rol atau kuas. Proses tersebut dilakukan berulang-ulang hingga ketebalan yang diinginkan tercapai.

\subsection{Uji Tarik}

Tujuan utama dilakukanya pengujian tarik yaitu untuk mengetahui regangan, tegangan dan modulus elastifitas suatu bahan dengan cara menarik bahan tersebut dengan alat uji tarik sampai spesimen tersebut putus. Spesimen yang digunakan untuk uji mengacu pada ASTM D 638 type I untuk material dengan ketebalan kurang dari $7 \mathrm{~mm}$. Spesimen uji untuk ASTM D 638 adalah sebagai berikut.

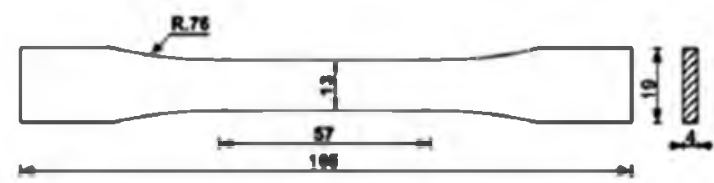

Gambar 1 Spesimen Uji Tarik

( ASTM D 638)

Hubungan linier antara tegangan regangan untuk suatu batang yang mengalami tarik atau tekan sehingga diperoleh modulus elastisitas material dinyatakan sebagai:

$\sigma=\mathrm{E} \varepsilon$

dimana hubungan antara beban tarik dan tegangan dinyatakan dalam persamaan 2 .

$\mathrm{F}=\sigma \mathrm{A}$

Sehingga,

$\varepsilon=\frac{\Delta L}{L o} \times 100 \%$

dengan :

$$
\begin{array}{ll}
E & : \text { Modulus Elastifitas (MPa) } \\
\varepsilon & : \text { Regangan }(\%) \\
\mathrm{F} & : \text { Beban tarik }(\mathrm{N}) \\
\mathrm{A} & : \text { Luas penampang }(\mathrm{mm} 2) \\
\sigma & : \text { Tegangan }(\mathrm{MPa}) \\
\Delta \mathrm{L} & : \text { Selisih panjang spesimen }(\mathrm{mm}) \\
\mathrm{L}_{\mathrm{o}} & : \text { Panjang mula mula }(\mathrm{mm})
\end{array}
$$

Besarnya regangan adalah jumlah pertambahan panjang karena pembebanan dibandingkan dengan panjang daerah ukur (gage length). Besarnya nilai modulus elastisitas komposit yang juga merupakan perbandingan antara tegangan dan regangan pada daerah proporsional dapat dihitung.

2.5 Uji Impak

Pengujian uji impak dilakukan untuk mengetahui besar penyerapan energi potensial yang dihasilkan dari pendulum yang diayunkan dari ketinggian kemudian secara tiba tiba menumbuk benda uji sehingga benda uji mengaalami deformasi. Untuk melakukan uji impak, telah ditentukan bahwa standart tes yang dilakukan adalah standart ASTM D 5994296 dengan tebal minimal $3,6 \mathrm{~mm}$.

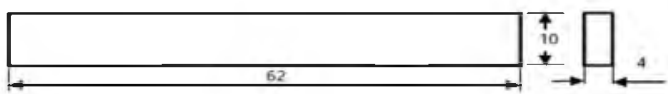

Gambar 2 Benda uji impak (ASTMD 5942-96) 
Pada pengujian standar Charpy dan Izod, dirancang dan masih digunakan untuk mengukur energi impak yang juga dikenal dengan ketangguhan takik.

$E_{s r p}=m g R(\cos \beta-\cos \alpha)$

(4)

dengan :

$\mathrm{E}_{\text {srp }} \quad$ : energi serap $(\boldsymbol{J})$

$\mathrm{m} \quad$ : berat pendulum $(\mathrm{kg})$

g : percepatan gravitasi $\left(\mathrm{m} / \mathrm{s}^{2}\right)$

$\mathrm{R}$ : panjang lengan (m)

$\alpha$ : sudut pendulum sebelum diayunkan $\left(^{\circ}\right)$

$\beta \quad$ : sudut ayunan pendulum setelah mematahkan spesimen $\left(^{\circ}\right)$

Harga impak dapat dihitung dengan:

$\mathrm{H}_{\mathrm{I}}=\mathrm{E}_{\mathrm{srp}} / \mathrm{A}_{0}$

dengan:

$\mathrm{H}_{\mathrm{l}} \quad$ : Harga Impak $\left(\mathrm{J} / \mathrm{mm}^{2}\right)$

E : energi serap $(J)$

$A_{0} \quad$ :Luas penampang $\left(\mathrm{mm}^{2}\right)$

\subsection{Uji Scanning Electron Microscope}

Scanning Electron Microscope (SEM) adalah salah satu jenis mikroscop electron yang menggunakan berkas electron untuk menggambarkan bentuk permukaan dari material yang dianalisis. Prinsip kerja dari SEM ini adalah dengan menggambarkan permukaan benda atau material dengan berkas electron yang dipantulkan dengan energy tinggi. Permukaan material yang disinari atau terkena berkas electron akan memantulkan kembali berkas electron atau dinamakan berkas electron sekunder ke segala arah.

3. Hasil dan Pembahasan

3.1 Hasil Uji Tarik

Pengujian kekuatan tarik komposit dengan penguat serbuk genteng soka bermatriks epoxy yang dilakukan pada fraksi volume $0 \%, 10 \%, 20 \%, 30 \%$, dan $40 \%$ dapat dilihat hasil pengujian tarik pada Tabel 2 .
Tabel 2 Hasil Uji tarik komposit serbuk genteng-epoxy

\begin{tabular}{ccc}
\hline \hline No & $\begin{array}{c}\text { Serbuk Genteng } \\
\text { (\% Volume) }\end{array}$ & $\begin{array}{c}\text { Kekuatan Tarik } \\
\text { (MPa) }\end{array}$ \\
\hline \hline 1 & 0 & 26,08 \\
2 & 10 & 49,14 \\
3 & 20 & 41,54 \\
4 & 30 & 29,76 \\
5 & 40 & 27,62 \\
\hline \hline
\end{tabular}

Tabel 2 menunjukan bahwa penambahan serbuk genteng sokka mempunyai pengaruh terhadap kekuatan mekanik pada komposit dengan matrik resin epoxy. Dari hasil pengujian tarik juga memperlihatkan bahwa komposit berpenguat serbuk genteng sokka dengan fraksi volume $10 \%, 20 \%, 30 \%$, dan $40 \%$ mengalami peningkatan kekuatan tarik bila dibandingkan dengan komposit tanpa penambahan serbuk genteng.

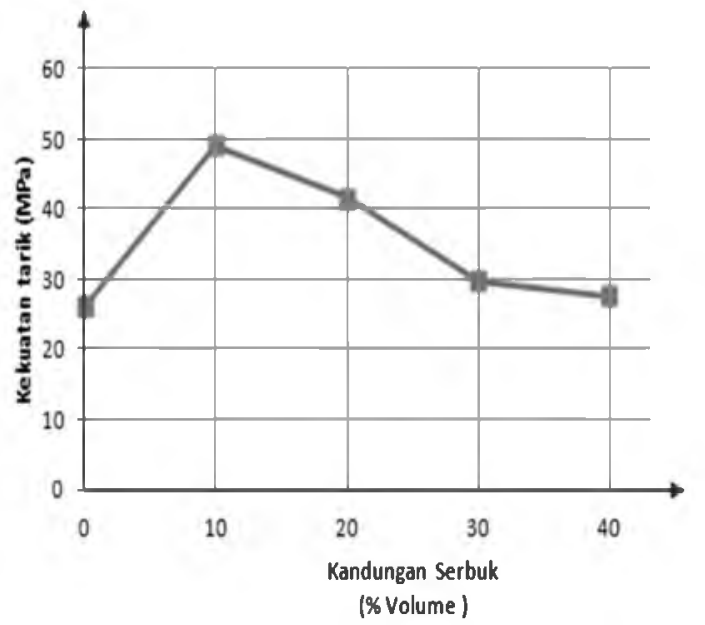

Gambar 3 Kekuatan Tarik vs \% vol. Serbuk Genteng

Gambar 3, menunjukan hubungan antara penambahan serbuk genteng sokka terhadap kekuatan tarik komposit yang dihasilkan. Dari gambar 3 juga dapat dilihat bahwa untuk penambahan serbuk genteng hingga $10 \%$ akan meningkatkan kekuatan tarik secara signifikan. Namun seiring dengan meningkatnya jumlah serbuk yang ditambahkan maka menyebabkan kekuatan tariknya cenderung menurun lagi hingga mencapai batas jenuhnya. Pada penambahan serbuk genteng sokka sebesar 40\% menghasilkan komposit bermatrik epoxy 
yang hampir sama dengan tanpa penambahan partikel serbuk genteng. Kekuatan tarik tertinggi diperoleh pada spesimen komposit dengan penambahan serbuk genteng sokka sebesar 10\% fraksi volume dengan kekuatan tarik sebesar 49, 14 MPa, sedangkan kekuatan tarik terendah yaitu pada komposit dengan penambahan serbuk genteng sokka sebesar $40 \%$ fraksi volume dengan kekuatan tarik sebesar 27 , $618 \mathrm{MPa}$.

Hal tersebut menunjukan bahwa naik turunya kekuatan tarik tidak hanya dipengaruhi oleh fraksi volume serbuk genteng sokka, tetapi juga dipengaruhi oleh proses manufaktur material komposit. Jika volume serbuk genteng sokka terlalu banyak, maka kemampuan partikel serbuk genteng sokka dalam memperkuat ikatan antar molekul matriks tidak akan maksimal. Proses manufaktur yang tidak maksimal menyebabkan partikel tidak menyebar secara merata dengan baik.

\subsection{Hasil Uji Impak}

Hasil pengujian kekuatan impak komposit bermatriks epoxy dengan penguat serbuk genteng sokka sebesar $0 \%, 10 \%$, $20 \%, 30 \%$, dan $40 \%$ fraksi volume dapat dilihat pada Tabel 3.

Tabel 3 Hasil Uji Impak Serbuk Genteng-

\begin{tabular}{cccc}
\multicolumn{4}{c}{ Epoxy } \\
\hline \hline No & $\begin{array}{c}\text { Serbuk Genteng } \\
\text { (\% Volume) }\end{array}$ & $\begin{array}{c}\text { Energi Serap } \\
\text { (Joule) }\end{array}$ & $\begin{array}{c}\text { Harga Impak } \\
\text { (Joule/mm })\end{array}$ \\
\hline \hline 1 & 0 & 1,14 & 0,0193 \\
2 & 10 & 2,24 & 0,0393 \\
3 & 20 & 2,24 & 0,0368 \\
4 & 30 & 2,24 & 0,0353 \\
5 & 40 & 2,24 & 0,0338 \\
\hline \hline
\end{tabular}

Tabel 3 menunjukan penambahan serbuk genteng sokka mempunyai pengaruh terhadap kekuatan impak dari komposit dengan matrik resin epoxy. Dari hasil pengujian impak juga memperlihatkan bahwa komposit berpenguat serbuk genteng sokka dengan fraksi volume $10 \%, 20 \%$, $30 \%$, dan $40 \%$ mengalami peningkatan nilai harga impak bila dibandingkan dengan komposit tanpa penambahan serbuk genteng.

Selanjutnya pada gambar 4 dapat dilihat komposit berpenguat serbuk genteng sokka dengan variasi fraksi volume $10 \%$ mengalami peningkatan kekuatan impak bila di bandingkan dengan fraksi volume $0 \%$ akan tetapi divariasi fraksi volume $20 \%$, $30 \%$, dan $40 \%$ menyebabkan penurunan kekuatan impak yang tidak signifikan. Untuk kekuatan impak tertinggi yaitu pada komposit fraksi volume $10 \%$ dengan kekuatan impak sebesar 0,0393 Joule/ $\mathrm{mm}^{2}$ sedangkan kekuatan impak terendah yaitu pada komposit fraksi volume $40 \%$ dengan kekuatan impak sebesar $0,0338 \mathrm{Joule} / \mathrm{mm}^{2}$.

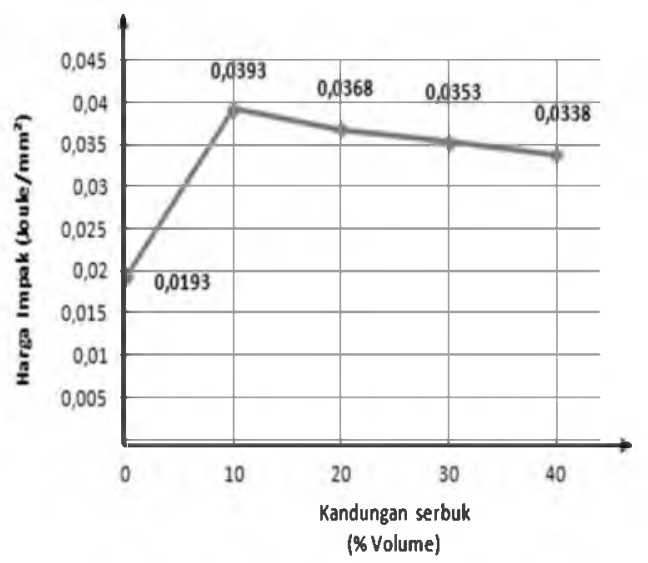

Gambar 4 Harga Impak vs \% Volume serbuk genteng sokka

Grafik pada Gambar 4, menunjukkan bahwa penambahan serbuk genteng sokka akan menyebabkan naik dan turunnya kekuatan impak pada komposit yang dihasilkan. Penambahan serbuk genteng samapai $10 \%$ fraksi volume menyebabkan akan meningkatnya kekeuatan impak, namun dengan semakin besar jumlah serbuk genteng yang ditambahkan maka akan menyebabkan kekuatannya menurun jika dibandingkan dengan variasi $10 \%$ fraksi volume serbuk genteng. Jika jumlah serbuk genteng sokka terlalu banyak maka kemampuan partikel serbuk genteng sokka dalam memperkuat ikatan antar molekul matriks tidak akan maksimal. Proses manufaktur yang tidak maksimal menyebabkan partikel tidak menyebar secara merata.

\subsection{Uji SEM}

Pengujian SEM dilakukan untuk mengetahui struktur morfologi dari material komposit yang diuji. Spesimen uji SEM 
(Scanning Electron Microscope) diambil dari permukaan patahan specimen pengujian tarik yang memiliki kekuatan tarik yang memiliki tegangan maksimum tertinggi. Hasil uji SEM yang dilakukan pada penelitian ini digunakan sebagai penunjang pada hasil uji tarik dan uji impak komposit.

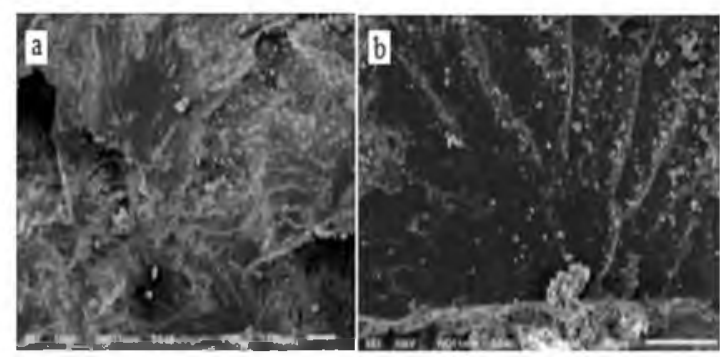

Gambar 5 Hasil SEM Penampang Patah

Dari hasil SEM pada Gambar 6 dapat dilihat adanya distribusi serbuk genteng sokka yang hampir merata pada setiap material komposit. Namun demikian masih terlihat adanya daerah yang belum terdapat distribusi serbuk genteng sokka yang secara merata. Hal ini kemungkinan terjadi karena proses mixing yang kurang sempurna, terlihat pula adanya sifat yang getas pada material, sifat getas ini merupakan sifat asli dari komposit itu sendiri. Kombinasi bentuk partikel yang dihasilkan cenderung beraglomerasi menjadi satu. Ini menunjukkan bahwa serbuk genteng Sokka memiliki sifat hygroscopis atau mudah menyerap air. Pada gambar $6 \mathrm{~b}$, terlihat adanya rambatan patah multilayer dalam jalur patah. Hal tersebut terjadi karena adanya penguat partikel genteng sokka yang meningkatkan kekuatan dari bahan komposit saat dilakukan pengujian tarik. Ukuran partikel serbuk genteng dari hasil uji SEM terletak dalam kisaran $5 \mu \mathrm{m}$ sampai $10 \mu \mathrm{m}$. Karena pada saat proses pengadukan hampir sebagian menjadi mikro karena terkena mata pengaduk dari mixer.

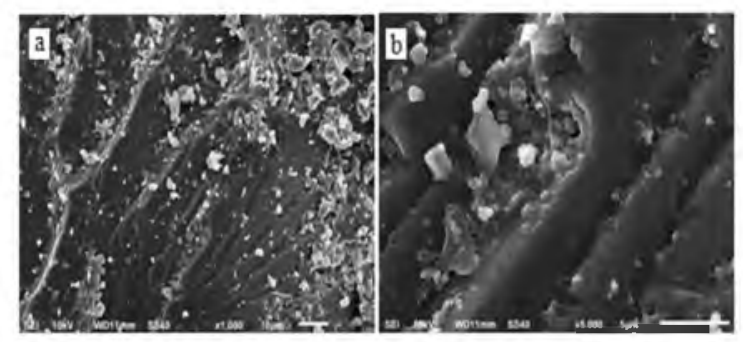

Gambar 6 Distribusi Serbuk Genteng Sokka

Gambar 6 memperlihatkan adanya mekanisme pull out. Hal ini terjadi karena adanya penggumpalan partikel genteng sokka yang tidak tercampur rata dalam matrik epoxy. Gumpalan parttikel yang ada disebabkan oleh perbedaan antara masa jenis partikel serbuk genteng dan resin epoxy. Dengan demikian pada proses pembuatan komposit setelah penuangan memiliki kemungkinan adanya cacat berupa distribusi serbuk yang tidak merata. Pada hasil SEM ini mendapatkan hasil tidak ditemukanya void atau udara yang terperangkap di dalam komposit dengan penguat serbuk genteng sokka ini.

\section{Kesimpulan}

1. Penambahan serbuk genteng sokka pada komposit bermatrik epoxy mampu meningkatkan kekuatan tarik komposit dengan nilai tertinggi dicapai pada variasi $10 \%$ fraksi volume dengan kekuatan tarik sebesar 49,14 MPa.

2. Penambahan serbuk genteng sokka pada komposit bermatrik epoxy mampu meningkatkan kekuatan impak dengan nilai tertingi diperoleh pada $10 \%$ fraksi volume dengan kekuatan impak sebesar $0,0393 \mathrm{Joule} / \mathrm{mm}^{2}$.

3. Hasil uji SEM menunjukan bahwa distribusi serbuk genteng sokka sangat dipengaruhi oleh karakteristik dan ukuran butiran serbuk genteng sokka yang digunakan.

\section{Saran}

Pada penelitian selanjutnya disarankan menggunakan ukuran partikel serbuk genteng sokka yang lebih halus serta melakukan modifikasi pada proses manufakturnya untuk mengurangi terjadinya cacat material komposit. Penambahan lempung bisa dipertimbangkan untuk mendapatkan hasil yang lebih baik.

\section{DAFTAR PUSTAKA}

[1] Diharjo dan Siswanto dkk., 2011, Pengaruh Fraksi Volume dan Ukuran Partikel Komposit Polyester Resin Berpenguat Genting Terhadap Kekuatan 
Tarik Dan Kekuatan Bending, UNS, Surakarta.

[2] Diharjo dkk., 2012, Sifat tahan Api dan Kekuatan Bending Komposit Geopolimer Analisis Pemilihan Jenis Partikel Geomaterial, UNS, Surakarta

[3] Diharjo dkk.,2013, Pengaruh Kandungan dan Ukuran Serbuk Genteng Sokka Terhadap Ketahanan Bakar Komposit Geopolimer, UNS, Surakarta.

[4] Siswanto dkk.,_, Perubahan Sifat Lentur Komposit High Density Polyethelene (HDPE) Terhadap Pengaruh Fraksi Volume Pengisi Serbuk Genteng Limbah, Politeknik Pratama Mulia, Surakarta.
[5] Nafi, 2013, Pengaruh Kandungan Partikel Dan Serat Serta Orientasi Serat Terhadap kekuatan Impak Komposit Serat Karbon-Serbuk Genteng SokkaPhenolic, Universitas Sebelas Maret, Surakarta.

[6] Armunanto, 2015, Sifat tarik dan Ketahanan Bakar Komposit Serbuk Genteng Sokka-Serat Gelas, Universitas Sebelas Maret, Surakarta.

[7] Schwartz, M.M,1984, Composite Material Handbook, Mcgraw-Hill, New York

[8] Gibson, J, et al, 1994, Principal of Composite Material Mechanics. MC. Graw Hill Inc. New York. 